\section{Measuring Fruit Cell Size and Estimating Changes in the Number of Fruit Cells by Replica or Video Microscope}

\author{
T. Sugiura and H. Honjo \\ Department of Pomology, Fruit Tree Research Station, Fujimoto Tsukuba \\ Ibaraki 305, Japan
}

\author{
M. Horimoto \\ Department of Fruit Tree, Agricultural Institute Hyogo, Beppumachi Kasai \\ Hyogo 679-01, Japan
}

Additional index words. Japanese pear, Pyrus pyrifolia, apple, Malus domestica

\begin{abstract}
Cell size in fruit flesh could be determined rapidly using a light microscope to inspect replicas obtained by pressing acetyl cellulose films or coatings on fruit flesh sections with nail polish. Alternatively, cell outlines in fruit sections stained with ink were observed directly using a video microscope. A test square drawn on a picture of cells was examined to rapidly evaluate mean cell size and the change in cell count.
\end{abstract}

Size differences in fruit are primarily due to differences in the size and number of constituent cells. There have been many studies about the measurement of cell size in fruit. For nearly all fixation processes for fruit flesh, paraffin or resin embedding and microtome sectioning is necessary before microscopic inspection (Ishida et al., 1973; Nakagawa and Nanjo, 1965; Nii and Nakashima, 1988; Ragland, 1934; Sinnott, 1939; Tukey and Young, 1939), which can take from several hours to several days. If used for frozen (Hirata et al., 1974) or hand-cut sections (Hosoi et al., 1964; Toyama and Hayashi, 1956), fixation and embedding are unnecessary, but the section cannot be preserved.

The replica method, useful in observing the material surfaces, has been used for measuring the number of stomata on leaves (Honjo et al., 1983; Ishihara et al., 1971; Zelitch, 1961) but has never been applied to inspecting cross sections of fruit flesh. Also, a video microscope can be used to view the material surfaces at high magnification. We report three experiments performed to develop methods for rapid measurement of fruit cell size by using replica methods or a video microscope.

\section{Materials and Methods}

Experiment 1. A Japanese pear fruit (Pyrus pyrifolia Nakai 'Kosui'), collected 43 days after flowering, was cut along the equatorial plane with a razor blade, and methyl acetate was applied on the section. The section was immediately pressed on a 0.08 -mm-thick acetyl

Received for publication 6 July 1994. Accepted for publication 15 Nov. 1994. This paper is contribution A-318 of Fruit Tree Research Station. We thank Y. Hase for advice. The cost of publishing this paper was defrayed in part by the payment of page charges. Under postal regulations, this paper therefore must be hereby marked advertisement solely to indicate this fact. pens. The stained surface was viewed directly by a video microscope (Olympus, Tokyo). intersected.
Cell outlines in the fruit flesh could be distinctly identified by film replica (Expt. 1, Fig. 1), nail-polish replica (Expt. 2, Fig. 2), and the video microscope (Expt. 3, Fig. 3) method. The time required for sample preparation was $2 \mathrm{~min}, 1 \mathrm{~h}$, and $1 \mathrm{~min}$ in Expts. 1 to 3 , respectively. A permanent reproduction of flesh cells was made more rapidly by the film replica than the polish method; however, cell walls in soft fruit, such as mature apples, may be crushed when the sections are pressed on films. Although samples have to be inspected before the surface becomes dry, observation with a video microscope was fastest. We assume that cells of other fruit types also can be observed by the polish method or with a video microscope if they are not crushed when cut with a razor blade.

Fruit cell sizes were compared by measuring the diameter of some of the largest cells, which generally were chosen by eye. However, the largest cells cannot always be chosen readily because, even within a region, there are considerable variations in apparent cell size, as cell division is taking place and cells have been cut at various levels. For speed and the ability to repeat cell-size determination, we suggest counting the number of cells intersected by the four sides of a test square drawn in each projected image (Fig. 1). The length of the sides are $\approx 10$ times as long as the cell diameter. The test square perimeter divided by the number of cells intersecting sides of the square is proportional to cell and intercellular space size. We termed this formula the celland space-size index (CSSI): CSSI (in micrometers) $=$ [test square perimeter (in micrometers)]/(number of cells intersecting sides of the square).

Although microscope power does not make a difference in the calculation, $\times 20$ to $\times 100$ magnification was best in our experiment. Tomkeieff (1945) indicated that the mean cell

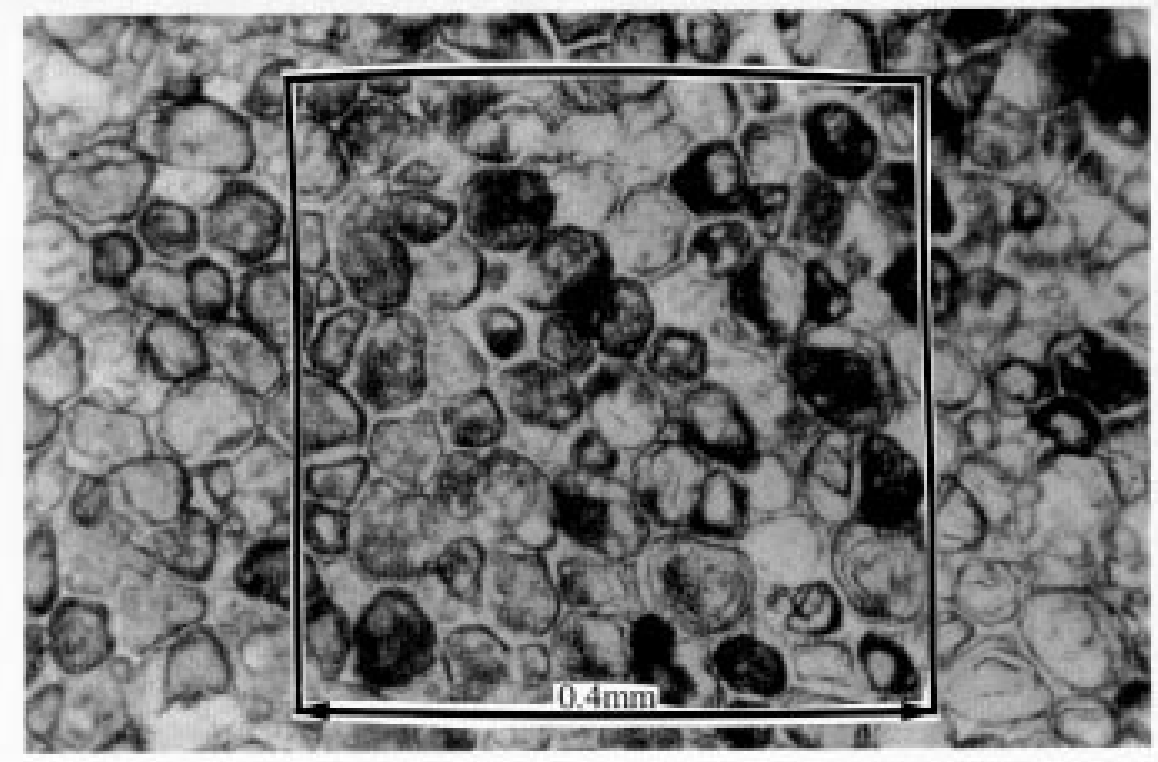

Fig. 1. A film replica of fruit flesh in Japanese pear and the test square for counting the number of cells 
intercept is related to the area divided by the perimeter. Considine (1978) and Considine and Knox (1981) determined cell size using the number of cells intersected per length of test line. If used for CSSI, measurement based on the number of cells intersecting the sides of the square, the effect of the direction of the test line on a plane, can be neglected. Assuming that each fruit is similar in cell shape, the CSSI can represent the cell and intercellular space size.

In many reports, change in fruit cell count has been evaluated from the relative growth

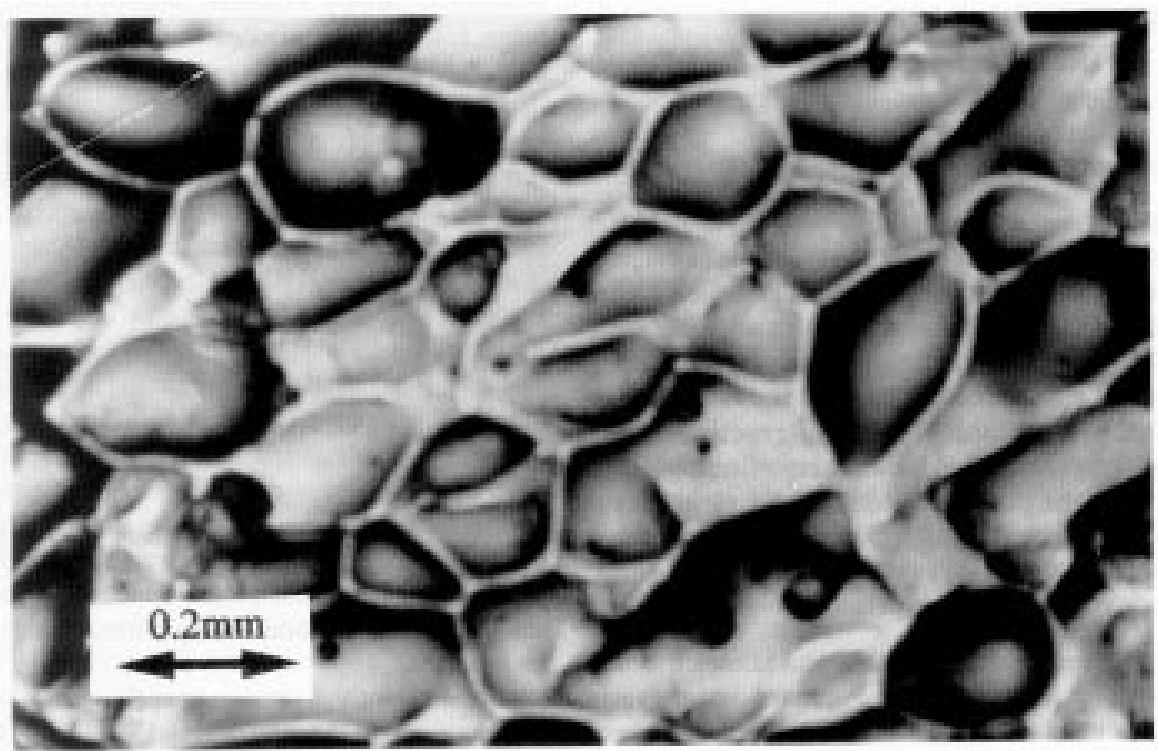

Fig. 2. A nail-polish replica of fruit flesh in a mature apple.

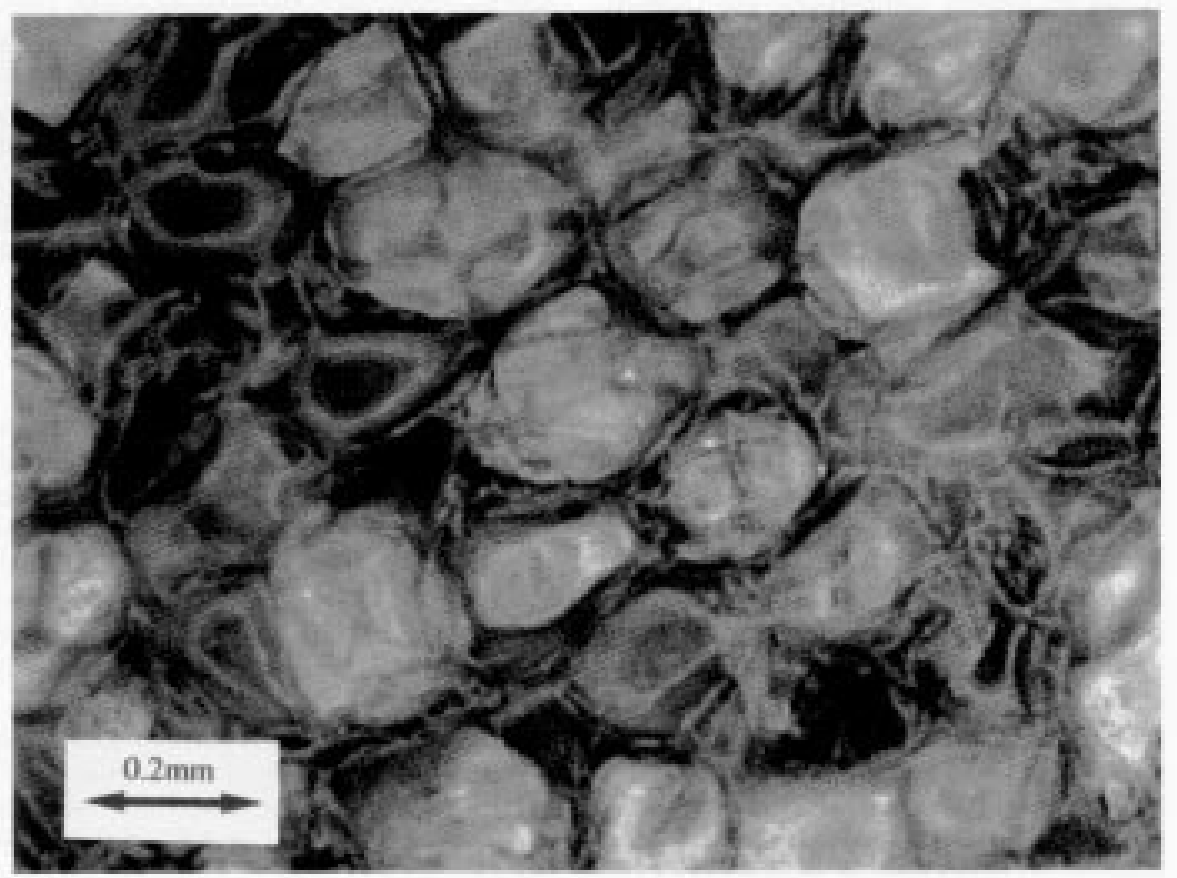

Fig. 3. A transverse section of mature apple fruit flesh under a video microscope. proportional to cell and intercellular space size, is used instead of cell diameter, a change in the number of fruit cells is evaluated more accurately by: $\ln Y=a^{\prime} \ln C S S I+b^{\prime}$, where $a^{\prime}$ is the relative growth constant and $b^{\prime}$ is constant.

We conclude that examining fruit cells by the replica method or by a video microscope facilitates speedy cell size measurement; also, CSSI is valuable for comparing cell size and estimating change in fruit cell count.

\section{Literature Cited}

Considine, J.A. 1978. Stereology of the dermal system of fruit. J. Microscopy 113:61-68.

Considine, J.A. and R.B. Knox. 1981. Tissue origins, cell lineages and patterns of cell division in the developing dermal system of the fruit of Vitis vinifera L. Planta 151:403-412.

Hirata, N., S. Hayashi, and H. Kurooka. 1974 Physiological studies of developing and ripening fruits of the Japanese persimmon. Tottori Univ. Bul. 26:15-27.

Honjo, H., T. Asakura, F. Kamota, and Y. Nakagawa 1983. Response in growth and development of fruit trees to controlled environment. Bul. Fruit Tree Res. Sta. A10:91-113.

Hosoi, T., K. Kadoya, and E. Yuda. 1964. Histological studies on the fruit development of pears as related to the nitrogen, phosphoric acid and potassium. 1. On the result of a four-year sand culture. J. Jpn. Soc. Hort. Sci. 33:29-34.

Huxley, J.S. and G. Teissier. 1936. Terminology of relative growth. Nature 137:780-781.

Ishida, M., A. Inaba, and Y. Sobajima. 1973. Physiological studies on the growth and development of peach fruits. 1. Anatomical changes during the development of peach fruits. Kyoto Prefectural Univ. Bul. 25:1-7.

Ishihara, K., T. Nishihara, and T. Ogura. 1971. The relationship between environmental factors and behavior of stomata in the rice plant. 1. On the measurement of the stomatal aperture. J. Soc. Crop Sci. 40:491-496.

Nakagawa, S. and Y. Nanjo. 1965. A morphological study of Delaware grape berries. J. Jpn. Soc. Hort. Sci. 34:85-95.

Nii, N. and M. Nakashima. 1988. Fruit development in relation to the cell division and enlargement of the flesh in Japanese apricot cv. Shirakaga. Meijo Univ. Bul. 24:37-43.

Ragland, C.H. 1934. The development of the peach fruit, with special reference to split-pit and gumming. Proc. Amer. Soc. Hort. Sci. 31:1-21.

Sinnott,E.W. 1939. A developmental analysis of the relation between cell size and fruit size in cucurbits. Amer. J. Bot. 26:179-189.

Tomkeieff, S.I. 1945. Linear intercepts, areas and volumes. Nature 155:24.

Toyama, S. and S. Hayashi. 1956. Studies on the fruit development of Japanese pears. 1. On the flesh cell-division, cell-enlargement and the relation between flesh cell-size and fruit size in some varieties. J. Jpn. Soc. Hort. Sci. 25:274278.

Tukey, H.B. and J.O. Young. 1939. Histological study of the developing fruit of the sour cherry. Bot. Gaz. 100:723-749.

Zelitch, I. 1961. Biochemical control of stomatal opening in leaves. Proc. Natl. Acad. Sci. 47:1423-1433. 